\title{
PENGARUH KOMITMEN DAN KEPUASAN TERHADAP LOYALITAS KONSUMEN MELALUI KEPERCAYAAN DALAM MENGGUNAKAN PRODUK JASA TITIP TOKO ONLINE
}

\author{
${ }^{1}$ Muhamad Rifa'i; ${ }^{2}$ Wisari Yati; ${ }^{3}$ Riski Aprilia Dwi Susanti \\ ${ }^{123}$ Fakultas Ekonomi, Universitas Tribhuwana Tunggadewi \\ E-mail: rifaiunitri@gmail.com
}

\begin{abstract}
The purpose of this research is to know and analyze: the influence of commitment to consumer confidence, the influence of satisfaction on trust, the influence of commitments that affect consumer loyalty, the influence of consumer satisfaction on loyalty, the influence of confidence in consumer loyalty, influence of consumer commitment to consumer loyalty through consumer confidence, and influence consumer satisfaction on loyalty through consumer confidence. The research population is a student in Malang City with sample of 91 respondents with judgmental sampling technique. The data used by the primary data collected through questionnaires, for the analysis of the data used is path analyisis. The results showed that consumer commitment was influential towards consumer confidence, satisfaction was influential in trust, a commitment to influence loyalty, customer satisfaction was influential towards loyalty, trust in loyalty, an influential commitment to loyalty through trust and satisfaction impacting loyalty through trust.
\end{abstract}

Keywords: commitment; satisfaction; customer loyalty; trust.

\section{ABSTRAK}

Tujuan penelitian ini adalah mengetahui serta menganalisis: pengaruh komitmen terhadap kepercayaan konsumen, pengaruh kepuasan terhadap kepercayaan, pengaruh komitmen berpengaruh terhadap loyalitas konsumen, pengaruh kepuasan konsumen terhadap loyalitas, pengaruh kepercayaan terhadap loyalitas konsumen, pengaruh komitmen konsumen terhadap loyalitas konsumen melalui kepercayaan konsumen, dan pengaruh kepuasan konsumen terhadap loyalitas melalui kepercayaan konsumen. Populasi penelitian adalah mahasiswa di kota Malang dengan sampel sebanyak 91 responden dengan teknik judgmental sampling. Data yang digunakan data primer yang dikumpulkan melalui kuesioner, untuk analisis data yang digunakan adalah analisis path. Hasil penelitian menujukkan bahwa komitmen konsumen berpengaruh terhadap kepercayaan konsumen, kepuasan berpengaruh terhadap kepercayaan, komitmen berpengaruh terhadap loyalitas, kepuasan konsumen berpengaruh terhadap loyalitas, kepercayaan berpengaruh terhadap loyalitas, komitmen berpengaruh terhadap loyalitas melalui kepercayaan dan kepuasan berpengaruh terhadap loyalitas melalui kepercayaan.

Kata Kunci: komitmen; kepuasan; loyalitas konsumen; kepercayaan.

\section{PEDAHULUAN}

Pada saat ini pemanfaatan media internet bayak digunakan oleh banyak kalangan, berdasarkan data survei tahun 2017 dari Asosiasi Penyelenggara Jasa Intrnet Indonesia (APJII) menujukkan jumlah data penggunaan internet di

Cara mengutip: Rifa'I, M., Yati, W., \& Susanti, R., A. 2020. Pengaruh Komitmen dan Kepuasan terhadap Loyalitas Konsumen melalui Kepercayaan dalam Menggunakan Produk Jasa Titip Toko Online. Referensi : Jurnal Ilmu Manajemen dan Akuntansi, $8(1), 61-72$ 
Indonesia sebanyak 143,26 juta jiwa atau dengan setara $54,7 \%$ dari total penduduk Indonesia. Dimana salah satu pemanfaatannya adalah bisa digunakan oleh para konsumen suatu produk untuk melaksanakan aktivitas belanja secara online. Berbelanja dengan cara online adalah suatu cara yang menudahkan para konsumen suatu produk untuk mendapatkan barang yang di inginkan dengan memanfaatkan teknologi informasi untuk mengetahui tentang barang yang di butuhkan serta diinginkan dengan cara yang lebih mudah dan cepat. Belanja secara online memberikan kemudahan bagi para konsumen mengunjungi toko dan memilih barang yang diinginkan melalui websitenya. Rifai \& Hamidi, (2017) menjelaskan banyak hal yang bisa dilakukan oleh pelaku bisnis untuk menarik konsumen dan memajukan bisnisnya dengan bisnis online, sistem penjualan toko yang pre-order.

Usaha jasa titip (personal shopper) merupakan bisnis baru dan sedang berkembang pesat seiring dengan pemanfaatan media internet melalui aplikasi media sosial yang saat ini berkembang, bahkan kehadiran lapak-lapak online menjadi suatu industri yang menarik di Indonesia dalam beberapa tahun terakhir. Keberadaan media sosial dan kepemilikan gadget oleh seseorang juga bisa dimanfaatkan untuk mengambil untung sebagai pembelanja pribadi atau personal shopper. Usaha jasa titip ini berkembang dan merupakan peluang bisnis yang cukup menarik, dimana usaha ini merupakan usaha yang dilakukan oleh seseorang baik di dalam maupun luar negeri yang membuka jasa pembelian barang yang diperlukan oleh konsumen. Awalnya bisnis jasa titip ini bermula dari konsumen yang membelikan produk untuk memenuhi pesanan konsumen. Namun pelaku bisnis jasa titip melihat peluang dari usaha ini bisa dikembangkan untuk mendapatkan keuntungan dari jasa pembelian titipan barang yang dipesan oleh konsumen lebih banyak lagi. Bermodalkan smartphone dan koneksi internet serta media sosial maka usaha jasa titip berubaah menjadi sektor usaha personal shopper yang memberikan keuntungan yang besar di berbagai pasar online yang sudah ada.

Kebanyakan konsumen yang lebih memilih jasa titip lebih dikarenakan para penguna bisa menitipkan barang dengan berbagai model yang diinginkan, konsumen juga bisa saling berkomunikasi soal harga hingga pemilihan barang yang ada di toko maupun official store. Pada dasarnya usaha jasa titip lebih mengedepankan aspek kepercayaan yang besar antara konsumen dan pelaku jasa titip karena pelaku jasa titip menjadi mata konsumen untuk memastikan barang yang di beli adalah asli atau sesuai harapan. Selain itu pelaku jasa titip bisa memastikan kondisi barang yang di pesan oleh konsumen dan pengguna jasa titip ini memiliki kesibukan dan sedikit waktu untuk pergi berbelanja ke store, dengan menggunakan jasa titip konsumen lebih tertarik menggunakannya karena pemesanan dengan jasa titip lebih mudah. Apalagi untuk barang-barang yang stok nya terbatas dan keberadaanya pada jam-jam tertentu pada online shop maupun di toko. Pada umumnya konsumen lebih terarik menggunakan jasa titip karena toko online jarang memfasilitasi beberapa promo yang ada di toko maka dengan begitu jasa titiplah yang menjadi pilihan mereka.

Namun hal yang penting yang harus difahami dalam usaha jasa titip ini adalah persoalan kepercayaan konsumen. Tanpa 
adanya kepercayaan suatu relationship tidak akan bertahan dalam jangka waktu yang panjang (Widyawati, 2008:96). Sikap (attitudes) konsumen adalah faktor penting yang akan mempengaruhi keputusan konsumen terhadap informasi suatu produk serta jasa. Konsep sikap terkait dengan konsep kepercayaan (belief) dan perilaku (behavior) konsumen. Sikap konsumen seringkali menggambarkan hubungan antara kepercayaan, sikap, dan perilaku. Konsumen biasanya memiliki kepercayaan terhadap atribut suatu produk atau jasa yang mana atribut tersebut merupakan image yang melekat (Ningsih, 2010:123). Oleh karena itu kepercayaan konsumen pada akhirnya akan berdampak pada kepuasan konsumen. kepuasan konsumen banyak digunakan untuk penelitian yang berkaitan dengan faktor yang mempengaruhi keputusan konsumen untuk melakukan transaksi dalam e-commerce (Wen, et al. 2011). Gefen, Karahanna \& Straub (2003:140) melakukan explorasi terhadap penggunaan ulang dapat ditujukan untuk seorang dalam melakukan pembelian online secara berulang dengan menggunakan internet, kondisi ini bisa terjadi karena adanya kepuasan yang dirasakan oleh konsumen tersebut.

Terjadinya kepuasan dan ketidakpuasan dalam pembelian konsumen untuk suatu produk juga mempengaruhi perilaku selanjutnya. konsumen puas, juga menunjukkan suatu hal yang tinggi dalam pembelian kembali produk tersebut (Kotler \& Keller, 2012:27) karena kepuasan merupakan bagian dari sebuah layanan yang mampu menghasilkan apa yang diinginkan oleh konsumen yang merupakan harapan mereka atas pelayanan ataupun hasil yang diterima setidaknya sama dengan harapan pelangan, atau akan melebihi dari apa yang diharapkan. Selanjutnya studi Hairany (2017) menujukkan kepuasan konsumen serta kepercayaan konsumen secara simultan berpengaruh secara signifikan bagi loyalitas pelanggan. Sementara itu hasil studi Lapasiang (2017) menunjukkan komitmen dan kepercayaan konsumen berpengaruh bagi loyalitas konsumen, kepercayaan konsumen secara parsial berpengaruh positif signifikan terhadap loyalitas maupun komitmen secara parsial positif berpengaruh tetapi tidak signifikan bagi loyalitas konsumen. Sementara studi Wardhani (2015) menunjukkan terdapat pengaruh kepercayaan konsumen dan kepuasan konsumen terhadap loyalitas serta kepercayaan dan kepuasan konsumen secara parsial dan simultan berpengaruh terhadap loyalitas.

Tujuan dalam penelitian ini adalah untuk mengetahui serta menganalisis: (1) pengaruh komitmen terhadap kepercayaan konsumen; (2) pengaruh kepuasan terhadap kepercayaan; (3) pengaruh komitmen berpengaruh terhadap loyalitas konsumen; (4) pengaruh kepuasan konsumen terhadap loyalitas; (5) pengaruh kepercayaan terhadap loyalitas konsumen; (6) pengaruh komitmen konsumen terhadap loyalitas konsumen melalui kepercayaan konsumen; dan (7) pengaruh kepuasan konsumen terhadap loyalitas melalui kepercayaan konsumen.

\section{METODE PENELITIAN}

Jenis penelitian yang digunakan adalah penelitian explanatory research, lokasi penelitian ini dilakukan di Universitas Tribhuwana Tunggadewi Malang, Sumber data dalam penelitian ini adalah mencakup dua jenis data yaitu data primer dan data skunder. Metode dalam 
pengumpulan data yang digunakan untuk penelitian ini adalah kuesioner (angket) dan dokumentasi. Dalam penelitian ini populasinya adalah para mahasiswa manajemen sebanyak 953 dengan pengambilan sampel sebayak 91 orang yang menggunakan teknik judgmental sampling yang juga merupakan teknik non probability sampling dengan memilih orang-orang yang terseleksi oleh peneliti serta berpengalaman dalam penggunaan jasa titip serta berdasarkan ciri-ciri khusus dan dimiliki oleh sampel yang sudah diketahui sebelumnya (Singgih dan Fandy, 2001: 90). Ciri-ciri khusus dalam penelitian ini yaitu mahasiswa jurusan manajemen Universitas Tribhuwana Tunggadewi Malang yang menggunakan jasa titip pada toko online pakaian lebih dari tiga kali. Adapun pertimbangan dalam pemilihan mahasiswa jurusan manajemen karena jurusan tersebut memiliki proporsi jumlah mahasiswa yang lebih banyak dibandingkan dengan jurusan yang lain. Kerangka penelitian disajikan pada gambar 1 berikut ini.

Gambar 1. Kerangka Penelitian

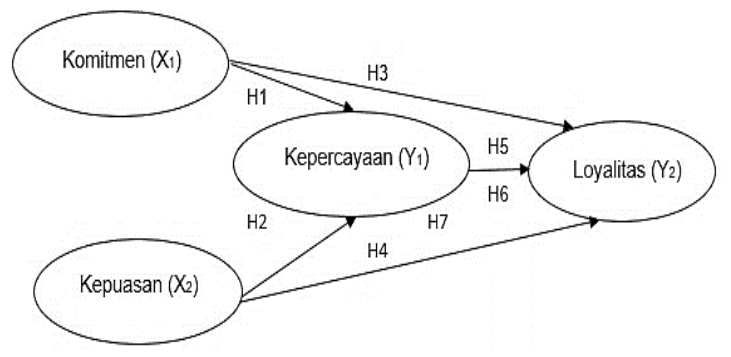

Metode analisis data yang digunakan untuk penelitian ini adalah analisis statistik deskriptif serta statistik inferensial yang menggunakan analisis jalur (path analysis). Analisis Jalur dikembangkan oleh Wright (1960) sebagai metode untuk mempelajari pengaruh langsung dan tidak langsung diantara variabel-variabel penjelas dan variabel-variabel terikat. Analisis jalur merupakan suatu bentuk terapan dari analisis multi regresi. Prinsip dasar menggunakan path analysis antara lain: (1) adanya linearitas; (2) hubungan antara variabel bersifat linier; (3) adanya aditivitas; (4) tidak ada efek-efek interaksi; (5) data berskala interval; (6) adanya rekursivitas semua anak panah mempunyai satu arah; (7) tidak boleh terjadi pemutaran kembali (looping); dan (8) terdapat masukan korelasi yang sesuai (Solimun, 2005:64).

\section{HASIL DAN PEMBAHASAN}

Saat ini media sosial dan kepemilikan ponsel di tengah masyarakat Indonesia membawa peluang bagi pertumbuhan bisnis jasa titip yang disebut personal shopper. Bisnis ini relatif baru dan sedang berkembang yang seiring dengan berkembangnya media sosial. Bukan hanya kehadiran lapak-lapak online saja yang menjadi industri yang menarik di Indonesia dalam beberapa tahun terakhir. Keberadaan media sosial dan kepemilikan gadget juga bisa di manfaatkan untuk mengambil untung sebagai pembelanja pribadi atau personal shopper. Dengan cara seseorang cukup datang ke mall atau pusat belanja tertentu, foto item yang hendak di jual, lalu kirim ke akun media sosial, dengan begitu produk itulah yang dapat dipesan oleh follower untuk transaksi konsumen mengirimkan uang dengan membelikan produk tersebut dan di kirim ke alamat konsumen. Bisnis jasa titip yang dilakukan oleh seorang pebelanja pribadi menjanjikan keuntungan yang cukup besar.

Usaha sebagai personal shopper yang hampir tidak membutuhkan modal. Bisnis ini jadi peluang usaha baru bagi masyarakat untuk menambah penghasilan. 
Kebanyakan masyarakat lebih memilih jastip di bandingkan berbelanja langsung pada toko online di karenakan para penguna bisa menitipkan barang dengan berbagai model yang di inginkan, konsumen juga bisa saling berkomunikasi soal harga hingga pemilihan barang yang ada di toko maupun official store, jasa titip mengedepankan aspek kepercayaan yang besar antara konsumen dan pelaku jastip karena pelaku jasa titip menjadi mata konsumen untuk memastikan barang yang di beli asli atau tidak.selain itu pelaku jastip bisa memastikan kondisi barang yang di pesan oleh konsumen dan pengguna jastip ini memiliki kesibukan dan sedikit waktu untuk pergi berbelanja ke store dan menggunakan jastip konsumen tertarik menggunakan jastip karena pemesanan dengan jastip lebih mudah apalagi untuk barang -barang yang stok nya sedikit dan di jam-jam tertentu pada online shop maupun di toko. konsumen lebih terarik menggunakan jastip karena toko online jarang memfasilitasi beberapa promo yang ada di toko maka dengan begitu jastip lah menjadi pilihan mereka.

Berdasarkan hasil uji statistik deskriptif yang digunakan untuk mendeskripsikan atau menggambarkan data yang telah terkumpul dari kuesioner mengenai tanggapan responden terhadap variabel bebas dan variabel terikat. Statistik deskriptif dalam penelitian ini jugaakan memberikan gambaran atau deskripsi suatu data yang dilihat dari nilai maksimum, minimum, rata-rata (mean), dan standar deviasi. Hasil pengujian statistik deskriptif dapat dijelaskan hasil statistik deskriptif bahwa variabel komitmen memiliki nilai minimum sebesar 20 dan nilai maksimum sebesar 45 , dengan perolehan nilai mean sebesar 35,77 dan nilai standar deviasi sebesar 4,590. Selanjutnya variabel kepuasan memiliki nilai minimum sebesar 14 dan nilai maksimum sebesar 30 dengan perolehan nilai mean sebesar 24,00 dan nilai standar deviasi sebesar 3,399. Variabel kepercayaan memiliki nilai minimum sebesar 20 dan nilai maksimum sebesar 44, dengan perolehan nilai mean sebesar 35,60 dan nilai standar deviasi sebesar 4,709. Sedangkan variabel loyalitas memiliki nilai minimum sebesar 15 dan nilai maksimum sebesar 29, dengan perolehan nilai mean sebesar 23,58 dan nilai standar deviasi sebesar 2,864.

Hasil uji Linearitas yang di lakukan terhadap variabel kepercayaan terhahadap loyalitas pada gambar di atas maka dapat di simpulkan dan dengan hasil yang dapat kita lihat jika di buat garis lurus dari sisi kiri ke kanan terdapat garis yang lurus dan dapat katakan bahwa hasil variabel kepercayaan terhadap loyalitas berhubungan linier.yaitu menunjukan suatu garis yang sama dapat di katakan bahwa variabel kepercayaan mempengaruhi variabel loyalitas. Hasil analisis mengenai hubungan antara variabel-variabel hasil penelitian ini mempunyai hubungan linier antara variabel komitmen dan kepuasan, melalui kepercayaan terhadap loyalitas maka dapat di ketahui bahwa nilai signifikan pada linieritas sebesar 0.000 karena nilai signifikan kurang dari 0,05 maka dapat di simpulkan bahwa antara variabel komitmen dan kepuasan terhadap loyalitas terdapat hubungan yang linier. Hasil penelitian menujukkan nilai signifikan pada linieritas sebesar 0.000. karena di peroleh nilai signifikan kurang dari 0,05 maka dapat di simpulkan bahwa antara variabel komitmen,kepuasan melalui kepercayaan 
terhadap loyalitas terdapat hubungan yang linier.

Model perluasan regresi yang digunakan untuk menguji keselarasan matriks korelasi dengan dua atau lebih model hubungan sebab akibat yang dibandingkan oleh peneliti. Modelnya digambarkan dalam bentuk gambar lingkaran dan panah dimana anak panah tunggal menunjukkan sebagai penyebab. Regresi dikenakan pada masing-masing variabel dalam suatu model sebagai variabel tergantung (pemberi respon) sedang yang lain sebagai penyebab. Pembobotan regresi diprediksikan dalam suatu model yang dibandingkan dengan matriks korelasi yang diobservasi untuk semua variabel dan dilakukan juga penghitungan uji keselarasan statistik. (Garson, 2003 dalam Sarwono, 2007). Setelah dilakukan uji hipotesis, maka langkah selanjutnya adalah melakukan perhitungan koefisien jalur. Pengujian koefisien jalur dilakukan secara langsung untuk mengetahui seberapa besar pengaruh langsung variabel independen berpengaruh terhadap variabel dependen. Hasil analisis menunjukkan bahwa pengaruh secara langsung antara komitmen terhadap kepercayaan yaitu sebesar 0,649 dan pengaruh secara langsung kepuasan terhadap kepercayaan yaitu sebesar 0,645. Adanya pengaruh secara langsung menunjukkan bahwa dengan semakin meningkatnya komitmen dan kepuasan maka kepercayaan akan mengalami peningkatan. Hasil analisis pengaruh secara langsung dapat diketahui bahwa komitmen berpengaruh terhadap loyalitas yaitu sebesar 0,540 dan kepuasan terhadap loyalitas yaitu sebesar 0,482. Adanya pengaruh secara langsung menunjukkan bahwa dengan semakin meningkatnya komitmen dan kepuasan maka loyalitas akan mengalami peningkatan. Pengaruh langsung, pengaruh tidak langsung dan pengaruh total antar variabel penelitian telah disajikan secara ringkas pada tabel 1 .

Tabel 1. Rekapitulasi Pengaruh Langsung, Tidak Langsung dan Pengaruh Total pada Variabel Komitmen dan Kepercayaan

\begin{tabular}{llllllll}
\hline Variabel & $\begin{array}{l}\text { Varaibel } \\
\text { Endogen }\end{array}$ & $\begin{array}{l}\text { Direct } \\
\text { Effect }\end{array}$ & $\begin{array}{l}\text { Indirect } \\
\text { Effect }\end{array}$ & $\begin{array}{l}\text { Total } \\
\text { Effect }\end{array}$ & t & Sig. & Kep. \\
\hline Komitmen & Loyalitas & 0,540 & 0 & 0,540 & 6,058 & 0,000 & Signifikan \\
& & & & & & & \\
Kepercayaan & Loyalitas & 0,679 & 0 & 0,679 & 8,722 & 0,000 & $\begin{array}{l}\text { Signifikan } \\
\text { Komitmen }\end{array}$ \\
Loyalitas & 0,540 & $\begin{array}{l}(0,540 \times 0,679) \\
=0,367\end{array}$ & 0,906 & 6,058 & 0,000 & Signifikan \\
N=91 & & & & & & & \\
\hline
\end{tabular}

Hasil analisis menunjukkan bahwa kepercayaan terbukti sebagai variabel intervening dalam hubungan antara komitmen dengan loyalitas. Hasil perhitungan menunjukkan pengaruh total lebih besar dari pada pengaruh secara langsung. Hal ini dibuktikan dengan hasil perhitungan Indirect Effect (IE) yang bernilai 0367, sedangkan komitmen terhadap loyalitas melalui kepercayaan yaitu sebesar 0,906. Pengaruh langsung, pengaruh tidak langsung dan pengaruh total antar variabel kepuasan dan kepercayaan telah disajikan secara ringkas pada tabel 2 . 
Referensi : Jurnal Ilmu Manajemen dan Akuntansi Vol. 8, No.1, 2020. Hal 61-72

Tabel 2. Rekapitulasi Pengaruh Langsung, Tidak Langsung dan Pengaruh Total pada Variabel Kepuasan dan Kepercayaan

\begin{tabular}{llllllll}
\hline Variabel & $\begin{array}{l}\text { Varaibel } \\
\text { Endogen }\end{array}$ & $\begin{array}{l}\text { Direct } \\
\text { Effect }\end{array}$ & $\begin{array}{l}\text { Indirect } \\
\text { Effect }\end{array}$ & $\begin{array}{l}\text { Total } \\
\text { Effect }\end{array}$ & $\mathrm{t}$ & Sig. & Kep. \\
\hline Kepuasan & Loyalitas & 0,482 & 0 & 0,482 & 5,185 & 0,000 & Signifikan \\
& & & & & & & \\
Kepercayaan & Loyalitas & 0,679 & 0 & 0,679 & 8,722 & 0,000 & Signifikan \\
Kepuasan & Loyalitas & 0,482 & $\begin{array}{l}(0,482 \times 0,679) \\
=0,327\end{array}$ & 0,809 & 5,185 & 0,000 & Signifikan \\
N=91 & & & & & & & \\
\hline
\end{tabular}

Tabel 2 menunjukkan bahwa kepercayaan terbukti sebagai variabel intervening dalam hubungan antara kepuasan dengan loyalitas. Hasil perhitungan menunjukkan pengaruh total lebih besar dari pada pengaruh secara langsung. Hal ini dibuktikan dengan hasil perhitungan Indirect Effect (IE) yang bernilai 0,327, sedangkan kepuasan terhadap loyalitas melalui kepercayaan yaitu sebesar 0,809. Goodness of fit Model digunakan untuk mengetahui besarnya keragaman variabel eksogen dalam menjelaskan keragaman variabel endogen, atau dengan kata lain untuk mengetahui besarnya kontribusi variabel eksogen terhadap variabel endogen. Goodness of fit Model dalam analisis Path dilakukan dengan menggunakan Koefisien Determinasi Total $\left(\mathrm{R} \_\mathrm{m}^{2}\right)$. Hasil perhitungan ketepatan model sebesar $58,6 \%$ menerangkan bahwa kontribusi model untuk menjelaskan hubungan struktural dari keempat variabel yang diteliti yaitu sebesar 58,6\%. Sedangkan sisanya sebesar $41,39 \%$ dijelaskan oleh variabel lain yang tidak terdapat dalam model penelitian ini.

\section{Pengaruh Komitmen Terhadap Kepercayaan}

Hasil analisis dapat diketahui bahwa terdapat pengaruh yang signifikan antara komitmen terhadap kepercayaan, artinya bahwa dengan semakin meningkatnya komitmen pelanggan maka kepercayaan juga akan mengalami peningkatan. Nilai bagi pelanggan bisa juga dilihat sebagai cerminan dari kualitas, manfaat dan pengorbanan yang diberikan untuk mendapatkan sebuah produk atau layanan.

Sebuah produk atau layanan perusahaan dikatakan mempunyai nilai yang tinggi di mata pelanggan apabila mampu memberikan kualitas, manfaat dan pengorbanan yang seminimal mungkin dan hal tersebut menjadi tolak ukur tingkat komitmen konsumen kepada produk dan layanan jasa yang ditawarkan kepada konsumen. Kepercayaan pelanggan didefinisikan sebagai pemikiran, perasaan, emosi, atau perilaku yang dimanifestasikan ketika pelanggan merasa bahwa penyedia dapat diandalkan untuk bertindak demi kepentingan terbaik mereka ketika mereka menyerahkan kontrol langsung (Leninkumar, 2017). Kepercayaan pelanggan berhubungan erat dengan kepuasan pelanggan terhadap suatu produk, jasa dan layanan. Kepercayaan pelanggan muncul karena adanya kepuasan yang diperoleh pelanggan dari hasil produk, jasa dan layanan yang dirasakan. Hasil penelitian ini mendukung penelitian terdahulu yang dilakukan oleh Ningtyas (2011) yang menunjukkan bahwa 
komitmen memiliki pengaruh yang signifikan terhadap kepercayaan konsumen.

\section{Pengaruh kepuasan konsumen terhadap kepercayaan konsumen}

Berdasarkan hasil analisis dapat diketahui bahwa terdapat pengaruh yang signifikan antara kepuasan konsumen terhadap kepercayaan konsumen, artinya bahwa dengan semakin meningkatnya kepuasan konsumen maka kepercayaan juga akan mengalami peningkatan. Kepuasan dapat diartikan sebagai upaya pemenuhan sesuatu atau membuat sesuatu memadai. Salah satu tujuan utama perusahaan khususnya perusahaan jasa dalam hal ini adalah bank adalah menciptakan kepuasan pelanggan. Kepuasan pelanggan sebagai hasil penilaian pelanggan terhadap apa yang diharapkannya dengan membeli dan mengkonsumsi suatu produk atau jasa. Kemudian harapan tersebut dibandingkan dengan kinerja yang diterimanya dengan mengkonsumsi produk/jasa tersebut, agar terciptanya konsumen yang loyal harus diimbangi dengan kepuasan yang diharpakan oleh konsumen. Hasil penelitian ini mendukung penelitian terdahulu yang dilakukan oleh Norhermaya dan Seosanto (2016) yang menunjukkan bahwa kepuasan memiliki pengaruh yang signifikan terhadap kepercayaan pelanggan.

\section{Pengaruh komitmen loyalitas pelanggan}

Dari hasil analisis dapat diketahui bahwa terdapat pengaruh yang signifikan antara komitmen terhadap loyalitas pelanggan, artinya bahwa dengan semakin meningakatnya komitmen pelanggan maka loyalitas juga akan mengalami peningkatan. Komitmen dirumuskan sebagai suatu bentuk perjanjian yang tersurat maupun tersirat untuk melanjutkan hubungan antar dua pihak atau lebih. Menurut Ellena (2011:24) komitmen adalah suatu hubungan yang berharga yang perlu dipertahankan terus, dimana masingmasing pihak bersedia bekerjasama untuk mempertahankan hubungan ini. Komitmen pelanggan dapat diartikan sebagai keinginan pelanggan yang berlangsung dalam waktu yang lama untuk mempertahankan hubungan yang bernilai atau menguntungkan dengan pihak perusahaan dan mendukung upaya menciptakan loyalitas pelanggan. Hasil penelitian ini mendukung penelitian terdahulu yang dilakukan oleh Davijani (2015) yang menunjukkan bahwa komitmen memiliki pengaruh yang signifikan terhadap loyalitas pelanggan.

\section{Pengaruh kepuasan terhadap loyalitas pelanggan}

Berdasarkan hasil analisis dapat diketahui bahwa terdapat pengaruh yang signifikan antara kepuasan terhadap loyalitas pelanggan, artinya bahwa dengan semakin meningkatnya kepuasan pelanggan maka loyalitas pelanggan juga akan mengalami peningkatan. Kepuasan pelanggan terhadap perusahaan dapat timbul karena terdapat pengalaman bertransaksi dengan perusahaan sehingga memberikan reaksi positif dari pelanggan. Kepuasan pelanggan akan menimbulkan sikap senang terhadap transaksi dan memberikan dampak besar pada kelangsungan usaha atau hubungan jangka panjang (Kurniasari dan Ernawati, 2012). Muktiono (2014) menyatakan bahwa kepuasan pelanggan akan mempengaruhi sikap pelanggan berikutnya setelah menggunakan atau merasakan produk 
maupun jasa yang ditawarkan, oleh karena itu pelanggan yang merasa puas akan mengulangi menggunakan jasa yang ditawarkan. Untuk itu, para penyedia jasa hendaknya memberikan kualitas yang baik untuk para pelanggan sehingga jumlah pelanggan dapat dipertahankan dan dikembangkan. Kepuasan konsumen juga menunjukkan tingkat perasaan seseorang setelah membandingkan sesuatu yang diharapkan dengan hasil yang diterima (Kotler dalam Tjiptono, 2014: 147). Harapan konsumen merupakan perkiraan atau keyakinan konsumen tentang apa yang akan diterimanya bila membeli atau menerima suatu produk barang atau jasa yang akan dijadikan standar dalam menilai manfaat produk tersebut. Kepuasan konsumen merupakan salah satu dari tujuan pemasaran yang secara erat dihubungkan dengan loyalitas konsumen (Zeithaml and Bitner, 2003).

Kepuasan telah terbukti memiliki pengaruh pada loyalitas pelanggan dalam studi-studi sebelumnya (Bloomer, et al 2008). Novitawati et al., (2019) menyatakan bahwa kualitas sangat berpengaruh terhadap loyalitas karena dapat mempertahankan kepercayaan pelanggan. Terjaminnya tingkat kepuasan konsumen yang lebih tinggi mengarah pada peningkatan keinginan untuk membeli sekaligus tingkat kesetiaan. Banyak peneliti setuju bahwa kepuasan pasca pembelian sangat berguna untuk menguatkan kepercayaan dan pilihan konsumen terhadap produk dan jasa yang mereka beli dan menguatkan keinginan mereka untuk membeli secara berulang. Hasil penelitian Castaneda (2010) memberikan gambaran mengenai pentingnya kepuasan pelanggan untuk menciptakan loyalitas pelanggan, dimana semakin meningkatnya kepuasan maka loyalitas pelanggan dapat terwujud dan dapat di rasakan oleh pelangan.

\section{Pengaruh kepercayaan terhadap loyalitas konsumen}

Dari hasil analisis dapat diketahui bahwa terdapat pengaruh yang signifikan antara kepercayaan terhadap loyalitas pelanggan, artinya bahwa dengan semakin meningkatnya kepercayaan pelanggan maka loyalitas pelanggan juga akan mengalami peningkatan. Kepercayaan merupakan dasar untuk terjadinya suatu transaksi jual beli online. Menurut Rahmawati (2013), Kepercayaan merupakan pondasi utama dari suatu bisnis. Suatu transaksi bisnis antara dua pihak atau lebih akan terjadi apabila masing-masing saling mempercayai satu sama lain.

Kepercayaan pelanggan akan ecommerce merupakan salah satu faktor kunci melakukan kegiatan jual beli secara online (Koufaris dan Hampton-Sosa, 2004). Kepercayaan juga merupakan hal utama yang harus dipertimbangkan oleh seorang pembeli ketika berbelanja secara online agar pelanggan percaya terhadap website yang menyediakan fasilitas layanan online shop dan penjual online yang ada pada situs web tersebut. Kepercayaan yang timbul pada transaksi jual beli online akan menimbulkan loyalitas seseorang untuk melakukan pembelian secara online dalam hal ini menggunakan jasa titip pada toko online pakaian.

\section{Pengaruh komitmen terhadap loyalitas konsumen melalui kepercayaan}

Berdasarkan hasil analisis dapat diketahui bahwa terdapat pengaruh yang signifikan antara komitmen terhadap loyalitas melalui kepercayaan, artinya bahwa dengan semakin meningkatnya pengaruh kepercayaan terhadap komitmen 
maka loyalitas juga akan mengalami peningkatan. Hasil analisis menunjukkan bahwa adanya rasa percaya pelanggan pada jasa titip pada toko online pakaian karena pelanggan tersebut yakin bahwa jasa titip pada toko online pakaian mampu memberikan nilai melebihi harapannya. Inti yang membuat pelanggan percaya pada jasa titip pada toko online pakaian adalah keterandalan janji yangdisampaikan kepada pelanggan, janji tersebut mampu dilaksanakan dan semuapersonil perusahaan komitmen untuk memenuhi janji tersebut. perusahaan ataumerek tertentu. Indikator kepercayaan yaitu meliputi: 1) kejujuran penjual dalam bertransaksi; 2) tanggungjawab penjual kepada pembeli; dan 3) kepercayaan bahwa perusahaan memiliki reputasi yang baik dapat meningkatkan kepuasan dan menciptakan loyalitas konsumen.

\section{Pengaruh kepuasan konsumen terhadap loyalitas konsumen melalui kepercayaan}

Hasil analisis dapat diketahui bahwa terdapat pengaruh yang signifikan antara kepuasan konsumen terhadap loyalitas pelanggan melalui kepercayaan, artinya bahwa dengan semakin meningkatnya pengaruh kepercayaan terhadap kepuasan maka loyalitas juga akan mengalami peningkatan. Unsur yang membuat konsumen percaya terhadap jasa titip adalah jasa titip memberikan layanan yang baik harga yang di tawarkan juga transparan dan juga di lihat dari akun-akun social media yang banyak followernya dan banyak juga komentar-komentar positif tentang jasa titip yang di jalan kan sehingga membuat banyak konsumen yang percaya terhadap layanan jasa titip. Kepuasan pelanggan didefinisikan sebagai tingkat perasaan di mana pelanggan menyatakan hasil perbandingan atas kinerja produk atau jasa yang diterima dan yang diharapkan (Lupiyoadi, 2006).

Kepuasan pelanggan diukur dengan 3 indikator yaitu Puas dengan pelayanan jasa titip pada toko online pakaian, Produk sesuai harapan, Jarang terdapat keluhan. Kepercayaan merupakan keyakinan bahwa kata atau janji seseorang dapat dipercaya dan seseorang akan memenuhi kewajibannya dalam sebuah hubungan pertukaran (Mayer dan Schoorman, 1995). Kepercayaan diukur dengan 3 indikator yaitu Informasi produk yang disampaikan benar, Identitas/ informasi penjual jelas, Jasa titip pada toko online pakaian mampun memberikan kesan jujur. Loyalitas pelanggan adalah komitmen yang mendalam untuk membeli ulang atau berlangganan suatu produk atau jasa secara konsisten di masa yang akan datang, dengan demikian mengakibatkan pengulangan pembelian merk yang sama walaupun dipengaruhi situasi dan upaya pemasaran yang mempunyai potensi untuk menyebabkan tindakan berpindah ke pihak lain (Oliver dalam Uncle, Rowling dan Hammond: 2003).

\section{KESIMPULAN}

Berdasarkan hasil penelitian dan pembahasan yang dilakukan maka dapat di tarik kesimpulan bahwa komitmen berpengaruh terhadap kepercayaan konsumen dalam menggunakan jasa titip pada toko online pakaian, artinya bahwa dengan semakin meningkatnya komitmen maka kepercayaan konsumen dalam menggunakan jasa titip pada toko online pakaian akan mengalami peningkatan. Untuk Kepuasan konsumen berpengaruh terhadap kepercayaan konsumen dalam menggunakan jasa titip pada toko online 
pakaian, artinya bahwa semakin meningkatnya kepuasan konsumen juga akan meningkatkan kepercayaan konsumen dalam menggunakan jasa titip pada toko online pakaian. Sedangkan komitmen berpengaruh terhadap loyalitas konsumen dalam menggunakan jasa titip pada toko online pakaian, artinya bahwa dengan semakin meningkatnya komitmen maka loyalitas konsumen dalam menggunakan jasa titip pada toko online pakaian akan mengalami peningkatan. Selanjutnya kepuasan konsumen berpengaruh terhadap loyalitas konsumen dalam menggunakan jasa titip pada toko online pakaian, artinya bahwa dengan semakin meningkatnya kepuasan konsumen maka loyalitas konsumen dalam menggunakan jasa titip pada toko online pakaian akan mengalami peningkatan. Untuk kepercayaan berpengaruh terhadap loyalitas konsumen dalam menggunakan jasa titip pada toko online pakaian, artinya bahwa dengan semakin meningkatnya kepercayaan maka loyalitas konsumen dalam menggunakan jasa titip pada toko online pakaian akan mengalami peningkatan.

Variabel Komitmen berpengaruh terhadap loyalitas konsumen melalui kepercayaan dalam menggunakan jasa titip pada toko online pakaian artinya semangkin meningkatnya pengaruh kepercayaan terhadap komitmen maka loyalitas juga akan mengalami peningkatan. Sedangkan Kepuasan konsumen berpengaruh terhadap loyalitas konsumen melalui kepercayaan dalam menggunakan jasa titip pada toko online artinyabahwa dengan semangkin meningkatnya pengaruh kepercayaan terhadap kepuasan maka loyalitas juga akian mengalami peningkatan.

\section{DAFTAR PUSTAKA}

Asosiasi Penyelenggara Jasa Internet Indonesia [APJII]. 2017. Profil Pengguna Internet Indonesia. Jakarta: Asosiasi Penyelenggara Jasa Internet Indonesia, diakses tanggal 11 Desember 2019.

Bloomer, et al. 2008. Investigating drivers of bank loyalty: the complex relationship between image, service quality and satisfaction. International Journal of Bank Marketing, Vol. 16. pp 276-286

Castaneda, J. A. 2010. Relationship Between Customer Satisfaction and Loyalty on the Internet. $J$ Bus Psychol.

Ellena, F. 2011. Analisis Pengaruh Kepercayaan, Komitmen, Komunikasi, dan Penanganan Keluhan Terhadap Loyalitas Nasabah (Studi Pada Nasabah PT. BRI (Persero) Tbk. Cabang Pemalang). Skripsi. Semarang: Fakultas Ekonomi UNDIP.

Ningtyas. F. 2011. Pengaruh Kepercayaan, Komitmen, Komunikasi, Penanganan Masalah dan Kepuasan Nasabah Terhadap Loyalitas Nasabah Bank Muamalat di Surabaya. Jurnal Muamalat, Vol.1 (1). p.51-60.

Gefen, D., Karahanna. E. and Straub, D.W. 2003. Trust and TAM in online shopping: An integrated model. MIS Quarterly. 27 (1) p. 51-90

Hairany, E. \& Marijati, S. 2017. Pengaruh Kepuasan Dan Kepercayaan Terhadap Loyalitas Pelanggan Lembaga Pengembangan Dan Sertifikasi Batu Mulia (LPSB) Di Martapura Kabupaten Banjar. Jurnal Wawasan Manajemen, Vol. 2, (3).

Kotler, P; \& Armstrong, G. 2008. Prinsipprinsip Pemasaran,Jilid 1, Erlangga, Jakarta.

Kotler, P. 2011. Manajemen Pemasaran di Indonesia: Analisis, Perencanaan, 
Implementasi dan Pengendalian. Jakarta: Penerbit Salemba Empat

Koufaris, M., Hampton-Sosa, W. 2004. The development of initial trust in an online company by new customers, Journal Information and Management, Vol. 41 (3), p. 377397.

Kurniasari \& Ernawati. N. 2012. Pengaruh Kepuasan Pelanggan, Kepercayaan dan Harga Terhadap Loyalitas Pelanggan Laundry Kencling Semarang. Jurnal USM Q-MAN Vol. 1 (3) h. 57-68.

Lapasiang, S. 2017. Pengaruh Kepercayaan Dan Komitmen Terhadap Loyalitas Nasabah Pada PT. Pegadaian (Persero) Cabang Karombasan Manado. Jurnal Emba: Jurnal Riset Ekonomi, Manajemen, Bisnis Dan Akuntansi, Vol. 3 (5). p. 3068-3077. Leninkumar, V. 2017. The Relationship between Customer Satisfaction and Customer Trust on Customer Loyalty, International Journal of Academic Research in Business and Social Sciences, Vol. 7 (4), p. 450465, April.

Lupiyoadi, H. 2006. Manajemen Pemasaran Jasa, Edisi Kedua. Jakarta: Penerbit Salemba Empat.

Mayer, R. C., Davis, J. H., \& Schoorman, F. D. 1995. An integrative model of organizational trust. The Academy of Management Review, Vol. 20 (3), p. 709-734.

Muktiono, K. V. 2014. Pengaruh Kualitas Pelayanan Inti dan Kualitas Pelayanan Periferal Terhadap Kepuasan Pelanggan Serta Dampaknya Terhadap Minat Word of Mouth pada Bengkel PT. Nasmoco Gombel Semarang. Jurnal Fakultas Ekonomika dan Bisnis Universitas Diponegoro Semarang.

Ningsih, E.R. 2010. Perilaku Konsumen, Kudus: Nora Media Enterprise.
Norhermaya, Y.A., \& Soesanto, H. 2016. Analisis pengaruh kepuasan pelanggan terhadap kepercayaan dan loyalitas pelanggan untuk meningkatkan minat beli ulang studi pada online store lazada.co.id. Journal of Management, 5 (3), 1-13. Novitawati, R.A.D., Mahfud, A., \& Sasongko, T. 2019. Pengaruh Kualitas Produk dan Harga terhadap Loyalitas Pelanggan pada Sanger Warung Kopi Aceh Kota Malang. Referensi: Jurnal Ilmu Manajemen dan Akutansi, 7(2), 130-136.

Rahmawati, S. A. 2013. Antecedent Keputusan Pembelian Online (Studi Kasus Online Purchasing). Skripsi Dipublikasikan. Universitas Diponegoro.

Rifa'i. M, dan Hamidi, 2017. Efektivitas Promosi Online Dalam Pengambilan Keputusan Oleh Konsumen, Jurnal Optima, Vol. 1 (2) h. 67-73.

Sarwono. J. 2007. Analisis Jalur Untuk Riset Bisnis. Yogyakarta: Andi.

Solimun. 2005. Stucture Equation Modelling (SEM), Lisrel \& Amos, Malang, Fakultas MIPA Universitas Brawijaya Malang.

Wardhani, N.I.K. 2015. Analisis Kualitas Produk dan Harga dalam Meningkatkan Loyalitas melalui Kepuasan Pelanggan pada Minuman Sari Buah Frutang. $J$. Neo-Bis 6, h. 64-75.

Wen, C; Prybutok, V.R dan Xu, C. 2011. An Integrated Model for Customer Online Repurchase Intention. 2011. Journal of Computer Information Systems.

Zeithaml, V A and Bitner, M.J. 2003. Service Marketing. Tata McGrawHill. 